\title{
Expression Level of MicroRNA-449a Predicts the Prognosis of Patients With Gastric Cancer
}

\author{
DAICHI ISHIKAWA, KOZO YOSHIKAWA, CHIE TAKASU, HIDEYA KASHIHARA, \\ MASAAKI NISHI, TAKUYA TOKUNAGA, JUN HIGASHIJIMA and MITSUO SHIMADA \\ Department of Surgery, Tokushima University, Tokushima, Japan
}

\begin{abstract}
Background: In previous studies, we demonstrated the significant role of microRNA-449a (miR-449a) in colorectal cancer with in vivo and clinical samples. The importance of miR-449a in gastric cancer is still to be elucidated. This study examined the impact of miR-449a expression in tumor tissue and serum and investigated its potential as a prognostic marker in gastric cancer. Materials and Methods: Sixty-six patients with gastric cancer who underwent surgery were included in the study. miR-449a expression in tumor tissue and serum were investigated by real-time polymerase chain reaction analysis. The association of miR-449a expression with clinicopathological factors and patient prognosis were also investigated. Results: miR-449a expression was lower in tumor tissue than non-tumor tissue. miR-449a in tumor tissue negatively correlated with the malignancy of tumor and clinical stage. Increased carcinoembryonic antigen (CEA) and carbohydrate antigen 19-9 (CA19-9) levels were seen at significantly higher frequencies in patients with low miR-449a expression. Patients with low miR-449a expression had poorer cancerspecific survival compared to those with high miR-449a expression. The univariate analysis showed that lymphovascular invasion, increased CEA and CA19-9 and a low expression of miR-449a were associated with a poorer 5-year cancer-specific survival. miR-449a expression level in serum correlated to that in tumor tissue and was also associated with tumor malignancy. Conclusion: The miR449 a level in tumor tissue might be useful as a prognostic indicator for patients with gastric cancer and miR-449a in serum appears to reflect its expression in tumor tissue.
\end{abstract}

Correspondence to: Daichi Ishikawa, MD, Ph.D., Department of Surgery, The University of Tokushima, 3-18-15 Kuramoto, Tokushima City, Tokushima, 770-8503, Japan. Tel: +81 886337137, Fax:+81 886319698, e-mail: daichi-19850125@hotmail.co.jp

Key Words: Gastric cancer, microRNAs, microRNA-449a, miR449a.
MicroRNAs (miRNAs) are a class of noncoding RNAs of 21-25 nucleotides. miRNAs regulate expression of genes by targeting the 3-untranslated regions of mRNAs, which results in miRNA degradation or inhibition of miRNA translation $(1,2)$. miRNAs are considered to regulate various aspects of cell physiology, including development, proliferation, differentiation and apoptosis (3). Abnormally expressed miRNAs were reported to act as oncogenes or tumor suppressors and to be associated with tumorigenesis $(4,5)$. In the gastroenterological field, miRNA-34a-5p was shown to suppress gastric metastasis, and its expression predicted recurrence in patients with stages II/III gastric cancer (6). Thus, miRNAs may be used as prognostic indicators and potential targets for cancer therapy.

$m i R-449 a$ is a member of the $m i R-449$ family. The $m i R$ 449 cluster contains sequences and secondary structures similar to those of the miR-34 family. Therefore, they have been classified as a single family of miRNAs. The expression of $m i R-449 a$ is reduced in several cancer types, such as prostate and bladder cancer $(3,7)$. Furthermore, $m i R$ $449 a$ regulates several genes associated with tumorigenesis, including the gene encoding c-MYC, histone deacetylase (HDAC) (8-11) and cell-division cycle 25 homolog A (CDC25A), suggesting that miR-449a may have oncogenic effects. Our previous study succeeded in the creation of a $m i R-449 a$-deficient mouse and demonstrated that the deficiency of miR-449a promoted azoxymethane and dextran sodium sulfate-induced colorectal tumorigenesis (12). The $m i R$-449a-deficient mouse showed higher expression of $\mathrm{Ki}$ 67 compared to the wild-type mouse, suggesting that the normal colorectal mucosa has a more proliferative phenotype. We also reported the significance of $m i R-449 a$ and its potential target HDAC1 in patients with colorectal cancer (13). However, the impact of miR-449a expression in gastric cancer is to date not well studied and still to be elucidated.

Various types of molecules, including microRNAs, found in liquid biopsy are reported to be possible new biomarkers (14). The greatest advantage of liquid biopsy is that it is less 
A

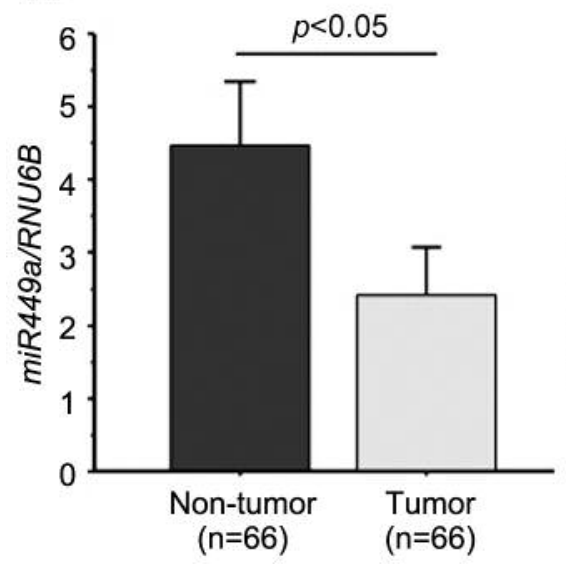

B

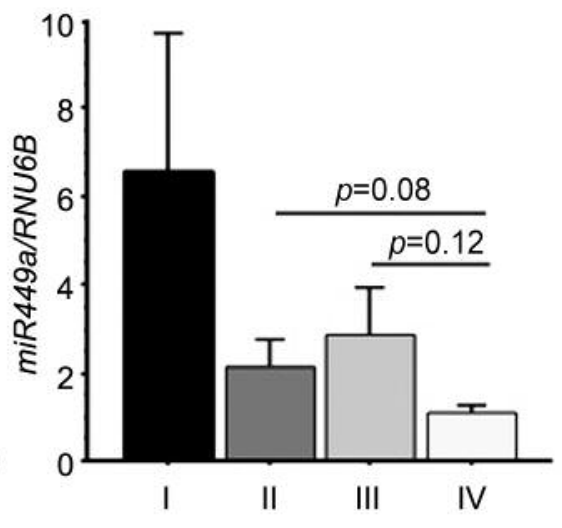

C

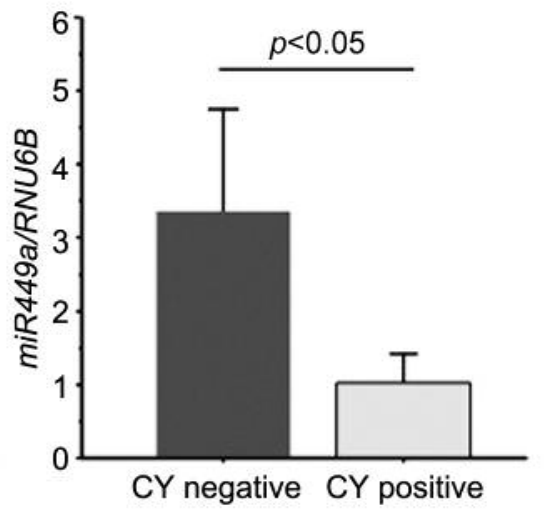

Figure 1. Expression level of miR-449a in gastric cancer tissue. A: Comparison of miR-449a expression between tumor and non-tumor tissue. In the tumor tissue, the expression of miR-449a was significantly lower than that of non-tumor tissue. B: Comparison of miR-449a expression according to stage. Patients with stage IV gastric cancer had relatively lower expression of miR-449a compared to those with stage II or III gastric cancer. $C$ : Comparison of miR-449a expression according to ascites cytology (CY). The expression of miR-449a in patients with cytology-positive ascites was significantly lower.

invasive for patients. Whether serum $m i R-449 a$ has clinical significance in gastric cancer is not yet known. The aim of this study was to investigate the significance of $m i R-449 a$ in tumor tissue and serum from patients with gastric cancer.

\section{Materials and Methods}

Patients and tissue samples. This study was approved by the Ethics Committee (approval number: 29001) of the Tokushima University Hospital and the patient information was obtained from their medical records. Sixty-six samples of gastric cancer were used to investigate tissue expression of $m i R-449 a$. For 18 patients, blood samples were collected preoperatively and serum was preserved for the investigation of $m i R-449 a$ in serum samples. The patients with gastric cancer underwent surgical resection at the Tokushima University Hospital from 2008 to 2010. Postoperatively, the patients were followed up using the level of tumor markers carcinoembryonic antigen (CEA) and carbohydrate antigen 19-9 (CA19-9), and computed tomography every 3 months to diagnose recurrence of the disease. The 5-year overall survival (OS), cancerspecific survival (i.e. death as a result of gastric cancer), and disease-free survival (DFS) were investigated. OS, cancer-specific survival and DFS were measured from the day of surgery. The prognostic factors were univariately analyzed. The staging of gastric cancer was performed according to the eighth edition of the American Joint Committee on Cancer Cancer Staging Manual (15).

miRNA expression analyses. Total RNA was isolated from resected specimen using miReasy kit (Qiagen, Hilden, Germany) following the manufacturer's instructions. Reverse transcription was carried out with the TaqMan ${ }^{\circledR}$ MicroRNA Reverse Transcription kit (Thermo Fisher Scientific, Waltham, MA, USA). For single miRNA assays, $25 \mathrm{ng}$ of total RNA including the was reverse transcribed with sequence-specific primers. For each quantitative polymerase chain reaction, 5-10 $\mathrm{ng}$ of the initial total RNA was used from cDNA samples. Every sample was amplified in triplicate using specific primer pairs using TaqMan ${ }^{\circledR}$ Gene Expression Master Mix (Thermo Fisher Scientific) according to the manufacturer's instructions. miRNA gene expression assay used Hs06632500_s1, hsa-miR-449 $a$ as a primer. Primer $h s a-R N U 6 B$ for RNA, U6 small nuclear 6 , pseudogene was used as an internal control for tissue and serum expression. All reactions were performed on a ViiA7 RealTime PCR system (Thermo Fisher Scientific). The standard curve method was used to evaluate the relative expression.

Statistical analysis. Statistical analyses were carried out using the JMP 10 statistical software package (SAS Institute Inc, Tokyo, Japan). Student's $t$-test was used for comparison of continuous variables. The chi-squared test was used to analyze the relationship between miR-449a expression and clinicopathological characteristics. The patients' survival data were plotted by the Kaplan-Meier method and analyzed by the log-rank test to calculate differences between the curves. A $p$-value of less than 0.05 was considered to be statistically significant.

\section{Results}

Expression level of $m i R-449 a$ in gastric cancer tissue. Expression of $m i R-449 a$ was compared between tumor and non-tumor tissue. In the tumor tissue, the expression of $m i R$ $449 a$ was significantly lower than that of non-tumor tissue (Figure 1A). In respect to the miR-449a expression according to stage, patients with stage IV gastric cancer had relatively lower expression level of miR-449a compared to those with stage II or III (Figure 1B). Furthermore miR-449a expression was significantly lower in patients with cytology-positive ascites (Figure 1C). 
Table I. Clinicopathological characteristics of patients according to expression of miR-449a.

\begin{tabular}{|c|c|c|c|c|}
\hline \multirow[t]{2}{*}{ Factor } & \multirow[b]{2}{*}{ Subgroup } & \multicolumn{2}{|c|}{$m i R-449 a$ expression } & \multirow[b]{2}{*}{$p$-Value } \\
\hline & & Low $(n=33)$ & High $(\mathrm{n}=33)$ & \\
\hline Age, years & Mean \pm SD & $71.4 \pm 11.6$ & $68.8 \pm 15.0$ & 0.42 \\
\hline Gender, $\mathrm{n}$ & Male/Female & $26 / 7$ & $28 / 5$ & 0.66 \\
\hline Location, $\mathrm{n}$ & Upper/Middle/Lower & $8 / 14 / 11$ & $5 / 17 / 11$ & 0.61 \\
\hline Size, $\mathrm{cm}$ & Mean \pm SD & $60.5 \pm 33.7$ & $57.9 \pm 35.1$ & 0.76 \\
\hline Depth, $\mathrm{n}$ & M,SM/MP,SS/SE,SI & $2 / 13 / 18$ & $8 / 12 / 13$ & 0.12 \\
\hline Differentiation & tub1,2/poor, sig & $14 / 19$ & $22 / 11$ & 0.09 \\
\hline Lymphatic invasion, $\mathrm{n}$ & $\mathrm{No} / \mathrm{Yes}$ & $7 / 26$ & $12 / 21$ & 0.22 \\
\hline Vascular invasion, $\mathrm{n}$ & $\mathrm{No} / \mathrm{Yes}$ & $9 / 24$ & $14 / 19$ & 0.26 \\
\hline $\mathrm{LN}$ metastasis, $\mathrm{n}$ & $\mathrm{No} / \mathrm{Yes}$ & $7 / 26$ & $12 / 21$ & 0.33 \\
\hline Stage, $\mathrm{n}$ & $\mathrm{I} / \mathrm{II} / \mathrm{III} / \mathrm{IV}$ & $4 / 7 / 12 / 10$ & $7 / 12 / 7 / 7$ & 0.80 \\
\hline CEA, $\mathrm{n}$ & $<5 / \geq 5 \mathrm{ng} / \mathrm{ml}$ & $23 / 10$ & $30 / 3$ & $<0.05$ \\
\hline CA19-9, n & $</ \geq 38 \mathrm{ng} / \mathrm{ml}$ & $17 / 16$ & $26 / 7$ & $<0.05$ \\
\hline
\end{tabular}

LN: Lymph node; CEA: carcinoembryonic antigen; CA19-9: carbohydrate antigen 19-9; M: mucosa; SM: submucosa; SS: subserosa; SE: serosa; SI: serosal invasion; tub1: well-differentiated tubular adenocarcinoma; tub2: moderately differentiated tubular adenocarcinoma; poor: poorly differentiated adenocarcinoma; sig: signet-ring cell carcinoma.

Patients were divided into two groups by the median value of $m i R-449 a$ expression (Table I). There was no difference in age, gender, tumor location, size, depth, lymphovascular invasion and lymph node metastasis. The frequency of less differentiated tumors tended to be higher in the group with low miR449a expression $(p=0.09)$. Increased CEA and CA19-9 levels were seen at significantly higher frequencies in the group with low miR-449a expression $(p<0.05)$.

Cancer-specific survival according to expression level of $m i R-449 a$ in tumor tissue. Figure 2 shows the cancer-specific survival according to expression of $m i R-449 a$ in tumor tissue. Patients with low expression of $m i R-449 a$ had worse cancer-specific survival than those with high expression of $m i R-449 a$. The univariate analysis showed that lymph node metastasis, lymphovascular invasion, increased levels of CEA and CA19-9 and a low expression of $m i R-449 a$ were significantly associated with poorer cancer-specific survival (Table II). Taken together, these results suggested that a low expression of $m i R-449 a$ in gastric cancer was correlated with higher malignancy of tumor and poorer prognosis.

Expression of miR-449a in serum reflects that in tumor tissue and is correlated with tumor malignancy. The expression of $m i R-449 a$ in serum was compared with that of the corresponding tissue sample. This revealed a tendency for positive correlation, as shown in Figure $3 \mathrm{~A}\left(\mathrm{R}^{2}=0.64\right.$, $p=0.12$ ). Regarding clinicopathological factors, $m i R-449 a$ expression in serum was lower in those with dedifferentiated gastric cancer compared to differentiated cancer. For other factors such as tumor size, lymphovascular invasion and depth of invasion, there was no correlation to the $m i R-449 a$ expression in serum samples. These results suggest that $m i R$ $449 a$ in serum might reflect the expression of $m i R-449 a$ in tumor tissue and could also be used as a biomarker preoperatively and in a less invasive manner than biopsy.

\section{Discussion}

In this study, the expression pattern and the significance of $m i R-449 a$ in gastric cancer were demonstrated. It was revealed that a low expression of $m i R-449 a$ is associated with increased level, of serum CEA and CA19-9. Although the type of cancer is different, $m i R-449 a$ expression was reported to be inversely correlated with the level of serum CEA in colon cancer $(7,13)$. The expression level of $m i R$ $449 a$ is reported to be frequently reduced in malignant tumor tissues, such as gastric and bladder cancer $(16,17)$. In these cancer types, $m i R-449 a$ is considered to inhibit cell growth or induce senescence and apoptosis by activating the p53 pathway.

This present study demonstrated the significance of $m i R$ $449 a$ as a prognostic indicator in the patients with gastric cancer. Previous reports also revealed that low expression of miR-449a would be a useful biomarker of bladder and prostate cancer, and medulloblastoma (18-21). In our previous work using knockdown of $m i R-449 a$ in mice, we showed that the lack of miR-449a contributes to the tumorigenesis of colorectal cancer and that $m i R-449 a$ regulated multL homolog $1(M L H 1)$ and Kirsten rat sarcoma viral oncogene homolog $(K R A S)$ (12). Other reports demonstrated that $m i R-449 a$ down-regulated oncogenes such 
Table II. Univariate analysis of 5-year cancer-specific survival (CSS).

\begin{tabular}{llcc}
\hline Factor & Subgroup & 5-Year CSS $(\%)$ & $p$-Value \\
\hline Age & $<70 / \geq 70$ Years & $80.0 / 59.7$ & 0.16 \\
Gender & Male/Female & $58.9 / 69.8$ & 0.43 \\
Differentiation & tub1, tub2/poor, sig & $67.1 / 54.7$ & 0.58 \\
LN metastasis & No/Yes & $90.0 / 51.1$ & $<0.05$ \\
Lymphatic invasion & No/Yes & $93.3 / 55.5$ & $<0.05$ \\
Vascular invasion & No/Yes & $83.8 / 51.5$ & $<0.05$ \\
CEA & $<5 / \geq 5 \mathrm{ng} / \mathrm{ml}$ & $69.2 / 30.8$ & $<0.05$ \\
CA19-9 & $</ \geq 38 \mathrm{ng} / \mathrm{ml}$ & $72.5 / 41.1$ & $<0.05$ \\
miR-449a & Low/High & $58.5 / 75.6$ & $<0.05$ \\
\hline
\end{tabular}

tub1: Well-differentiated tubular adenocarcinoma; tub2: moderately differentiated tubular adenocarcinoma; poor: poorly differentiated adenocarcinoma; sig: signet-ring cell carcinoma; LN: lymph node; CEA: carcinoembryonic antigen; CA19-9: carbohydrate antigen 19-9.

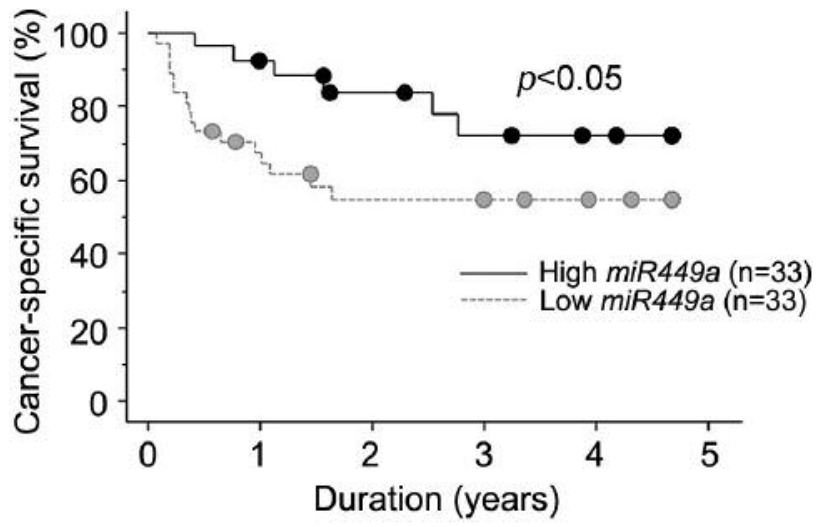

Figure 2. Cancer-specific survival according to expression level of miR449 a in gastric tumor tissue. Patients with low expression of miR-449a had worse cancer-specific survival than those with high expression.
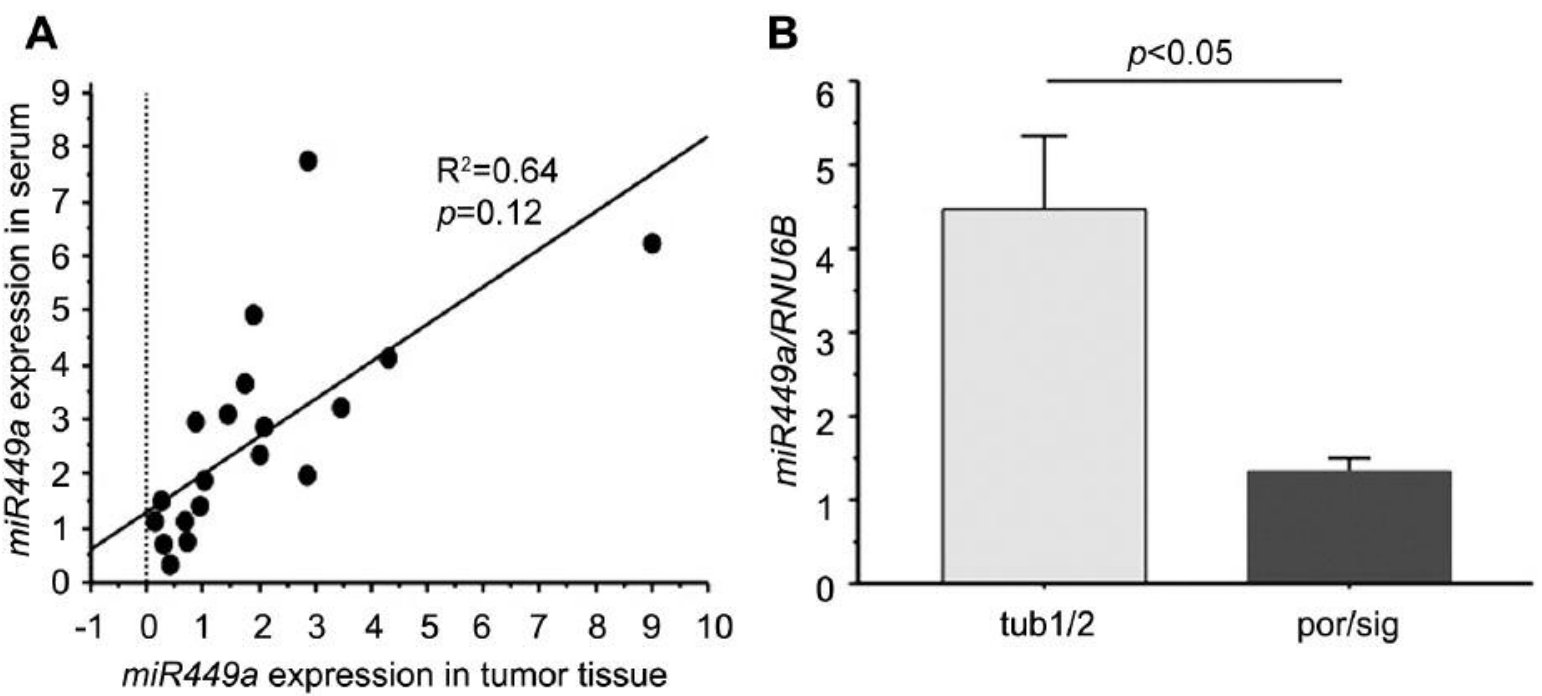

Figure 3. The expression of miR-449a in serum samples reflected the expression in tumor tissue and correlated with tumor malignancy. A: Positive correlation between miR-449a expression in tumor tissue and corresponding serum. B: miR-449a expression in serum was lower in two dedifferentiated gastric cancer compared to differentiated cancer.

as HDAC1, transforming growth factor- $\beta(T G F B)$, special AT-rich sequence-binding protein 2 (SATB2), a disintegrin and metalloproteinase domain-containing protein 10 (ADAM10), MYC and mitogen-activated protein kinase 1 (MAPKl) $(1-4,17,20)$.

Compared to diagnostics by tissue sampling, body fluid samples are easier to obtain and causes less harm to patients. Since Mitchell et al. confirmed that $m i R-141$ in plasma can be used as a diagnostic marker for prostate cancer (22), new circulating miRNAs have emerged as markers for tumor diagnosis. Serum expression levels of $m i R-18 a-5 \mathrm{p}, m i R-21$ - 5p, $m i R-29 a-5 \mathrm{p}, m i R-92 a-5 \mathrm{p}, m i R-143-5 \mathrm{p}$ and $m i R-378-5 \mathrm{p}$ were reported to be significantly less expressed in patients with colorectal cancer (23). We demonstrated a tendency for positive correlation between serum and tissue levels of $m i R$ $449 a$, and $m i R-449 a$ expression in serum was lower in those with dedifferentiated gastric cancer compared to differentiated cancer. miRNAs are stable in plasma, and there was no change in plasma expression level of miRNAs even when it was boiled at $100^{\circ} \mathrm{C}$ for $10 \mathrm{~min}$, kept at room temperature, or repeatedly frozen and thawed at room temperature (24). There is a current hypothesis that miRNAs 
in plasma are present in exosomes, complexes, or microvesicles secreted by tumor cells (25). This makes miRNAs suitable biomarkers of disease.

The limitation of this study is the shortage of samples and the lack of detailed in vitro or in vivo analysis to determine the role of $m i R-449 a$. Further detailed examination is needed to confirm the descriptive data presented in this study.

In conclusion, $m i R-449 a$ in serum appears to reflect the expression of $m i R-449 a$ in tumor tissue and the results of this study suggest that a low expression of $m i R-449 a$ might be a useful prognostic biomarker for the patients with gastric cancer.

\section{Conflicts of Interest}

None of the Authors has any potential financial conflicts of interest related to this study.

\section{Authors' Contributions}

Ishikawa D designed and carried out the experiment and wrote the initial draft of the article. Yoshikawa $\mathrm{K}$ and Takasu $\mathrm{C}$ contributed to analysis and interpretation of data. Tokunaga $\mathrm{T}$ and Higashijima $\mathrm{J}$ contributed to data collection and interpretation. Kashihara $\mathrm{H}$ and Nishi $M$ assisted in the preparation of the article. Shimada M supervised the project. All Authors have critically reviewed the article, approved the final version of the article.

\section{References}

1 Noonan EJ, Place RF, Pookot D, Basak S, Whitson JM, Hirata $\mathrm{H}$, Giardina C and Dahiya R: $m i R-449 a$ targets HDAC-1 and induces growth arrest in prostate cancer. Oncogene 28(14): 1714-1724, 2009. PMID: 19252524. DOI: 10.1038/onc.2009.19

2 Yang X, Feng M, Jiang X, Wu Z, Li Z, Aau M and Yu Q: Mir$449 \mathrm{a}$ and mir-449b are direct transcriptional targets of E2F1 and negatively regulate PRB-E2F1 activity through a feedback loop by targeting CDK6 and CDC25A. Genes Dev 23(20): 23882393, 2009. PMID: 2764491. DOI: 10.1101/gad.1819009

3 Lize $M$, Pilarski $S$ and Dobbelstein $M$ : E2F1-inducible microRNA $449 \mathrm{a} / \mathrm{b}$ suppresses cell proliferation and promotes apoptosis. Cell Death Differ 17(3): 452-458, 2010. PMID. DOI: 10.1038/cdd.2009.188

4 Luo W, Huang B, Li Z, Li H, Sun L, Zhang Q, Qiu X and Wang E: MicroRNA-449a is downregulated in non-small cell lung cancer and inhibits migration and invasion by targeting c-MET. PLoS One 8(5): e64759, 2013. PMID: 3667122. DOI: 10.1371/journal.pone.0064759

5 Wang $\mathrm{Z}$ and Burke PA: The role of microRNAs in hepatocyte nuclear factor-4alpha expression and transactivation. Biochim Biophys Acta 1829(5): 436-442, 2013. PMID: 23298640. DOI: 10.1016/j.bbagrm.2012.12.009

6 Ramamoorthy A, Li L, Gaedigk A, Bradford LD, Benson EA, Flockhart DA and Skaar TC: In silico and in vitro identification of microRNAs that regulate hepatic nuclear factor 4alpha expression. Drug Metab Dispos 40(4): 726-733, 2012. PMID: 3310421. DOI: 10.1124/dmd.111.040329
7 Chen H, Lin YW, Mao YQ, Wu J, Liu YF, Zheng XY and Xie LP: MicroRNA-449a acts as a tumor suppressor in human bladder cancer through the regulation of pocket proteins. Cancer Lett 320(1): 40-47, 2012. PMID: 22266187. DOI: 10.1016/ j.canlet.2012.01.027

8 Hoesel B, Bhujabal Z, Przemeck GK, Kurz-Drexler A, Weisenhorn DM, Angelis MH and Beckers J: Combination of in silico and in situ hybridisation approaches to identify potential DLL1 associated miRNAS during mouse embryogenesis. Gene Expr Patterns 10(6): 265-273, 2010. PMID: 20558326. DOI: 10.1016/j.gep.2010.06.002

9 Halappanavar S, Jackson P, Williams A, Jensen KA, Hougaard KS, Vogel U, Yauk CL and Wallin H: Pulmonary response to surface-coated nanotitanium dioxide particles includes induction of acute phase response genes, inflammatory cascades, and changes in microRNAS: A toxicogenomic study. Environ Mol Mutagen 52(6): 425-439, 2011. PMID: 3210826. DOI: $10.1002 / \mathrm{em} .20639$

10 Jeon HS, Lee SY, Lee EJ, Yun SC, Cha EJ, Choi E, Na MJ, Park JY, Kang J and Son JW: Combining microRNA-449a/b with a HDAC inhibitor has a synergistic effect on growth arrest in lung cancer. Lung Cancer 76(2): 171-176, 2012. PMID: 22078727. DOI: 10.1016/j.lungcan.2011.10.012

11 Bao J, Li D, Wang L, Wu J, Hu Y, Wang Z, Chen Y, Cao X, Jiang C, Yan W and Xu C: MicroRNA-449 and microRNA$34 \mathrm{~b} / \mathrm{c}$ function redundantly in murine testes by targeting E2F transcription factor-retinoblastoma protein (E2F-PRB) pathway. J Biol Chem 287(26): 21686-21698, 2012. PMID: 3381132. DOI: $10.1074 /$ jbc.M111.328054

12 Niki M, Nakajima K, Ishikawa D, Nishida J, Ishifune C, Tsukumo SI, Shimada M, Nagahiro S, Mitamura Y and Yasutomo K: MicroRNA-449a deficiency promotes colon carcinogenesis. Sci Rep 7(1): 10696, 2017. PMID: 5587792. DOI: $10.1038 / \mathrm{s} 41598-017-10500-0$

13 Ishikawa D, Takasu C, Kashihara H, Nishi M, Tokunaga T, Higashijima J, Yoshikawa K, Yasutomo K and Shimada M: The significance of microRNA-449a and its potential target HDAC1 in patients with colorectal cancer. Anticancer Res 39(6): 28552860, 2019. PMID: 31177123. DOI: 10.21873/anticanres.13414

14 Mitchell PS, Parkin RK, Kroh EM, Fritz BR, Wyman SK, Pogosova-Agadjanyan EL, Peterson A, Noteboom J, O’Briant KC, Allen A, Lin DW, Urban N, Drescher CW, Knudsen BS, Stirewalt DL, Gentleman R, Vessella RL, Nelson PS, Martin DB and Tewari M: Circulating microRNAS as stable blood-based markers for cancer detection. Proc Natl Acad Sci USA 105(30): 10513-10518, 2008. PMID: 18663219. DOI: 10.1073/pnas.0804549105

15 Amin MB, Edge S, Greene F, Byrd DR, Brookland RK, Washington MK, Gershenwald JE, Compton CC, Hess KR, Sullivan DC, Jessup JM, Brierley JD, Gaspar LE, Schilsky RL, Balch CM, Winchester DP, Asare EA, Madera M, Gress DM and Meyer LR: AJCC Cancer Staging Manual, 8th ed. Springer, New York, 2017.

16 Lai CY, Yu SL, Hsieh MH, Chen CH, Chen HY, Wen CC, Huang YH, Hsiao PC, Hsiao CK, Liu CM, Yang PC, Hwu HG and Chen WJ: Microrna expression aberration as potential peripheral blood biomarkers for schizophrenia. PLoS One 6(6): e21635, 2011. PMID: 3126851. DOI: 10.1371/journal.pone.0021635

17 Buurman R, Gurlevik E, Schaffer V, Eilers M, Sandbothe M, Kreipe H, Wilkens L, Schlegelberger B, Kuhnel F and Skawran B: Histone deacetylases activate hepatocyte growth factor 
signaling by repressing microRNA-449 in hepatocellular carcinoma cells. Gastroenterology 143(3): 811-820 e811-815, 2012. PMID: 22641068. DOI: 10.1053/j.gastro.2012.05.033

18 Jukic DM, Rao UN, Kelly L, Skaf JS, Drogowski LM, Kirkwood JM and Panelli MC: MicroRNA profiling analysis of differences between the melanoma of young adults and older adults. J Transl Med 8: 27, 2010. PMID: 2855523. DOI: 10.1186/1479-5876-8-27

19 Marcet B, Chevalier B, Luxardi G, Coraux C, Zaragosi LE, Cibois M, Robbe-Sermesant K, Jolly T, Cardinaud B, Moreilhon C, Giovannini-Chami L, Nawrocki-Raby B, Birembaut P, Waldmann R, Kodjabachian L and Barbry P: Control of vertebrate multiciliogenesis by mir-449 through direct repression of the delta/notch pathway. Nat Cell Biol 13(6): 693-699, 2011. PMID: 21602795. DOI: 10.1038/ncb2241

20 Bou Kheir T, Futoma-Kazmierczak E, Jacobsen A, Krogh A, Bardram L, Hother C, Gronbaek K, Federspiel B, Lund AH and Friis-Hansen L: $m i R-449$ inhibits cell proliferation and is downregulated in gastric cancer. Mol Cancer 10: 29, 2011. PMID: 3070685. DOI: $10.1186 / 1476-4598-10-29$

21 Rudolf E, John S and Cervinka M: Irinotecan induces senescence and apoptosis in colonic cells in vitro. Toxicol Lett 214(1): 1-8, 2012. PMID: 22898888. DOI: 10.1016/j.toxlet. 2012.08 .004
22 Mitchell $\mathrm{C}$ and Willenbring $\mathrm{H}$ : A reproducible and well-tolerated method for $2 / 3$ partial hepatectomy in mice. Nat Protoc 3(7): 1167-1170, 2008. PMID: 18600221. DOI: 10.1038/nprot. 2008.80

23 Clancy C, Joyce MR and Kerin MJ: The use of circulating microRNAS as diagnostic biomarkers in colorectal cancer. Cancer Biomark 15(2): 103-113, 2015. PMID: 25547322. DOI: 10.3233/CBM-140456

24 Ho AS, Huang X, Cao H, Christman-Skieller C, Bennewith K, Le QT and Koong AC: Circulating $m i R-210$ as a novel hypoxia marker in pancreatic cancer. Transl Oncol 3(2): 109-113, 2010. PMID: 20360935. DOI: 10.1593/tlo.09256

25 Jones LB, Bell CR, Bibb KE, Gu L, Coats MT and Matthews QL: Pathogens and their effect on exosome biogenesis and composition. Biomedicines 6(3), 2018. PMID: 30041409. DOI: 10.3390/biomedicines6030079
Received November 29, 2019

Revised December 9, 2019

Accepted December 12, 2019 